\title{
AN UNUSUAL FINDING OF A PARASITIC GAMASID MITE MACRONYSSUS HETEROMORPHUS DUSBÁBEK, RADOVSKY, 1972 (MESOSTIGMATA: GAMASINA: MACRONYSSIDAE) IN THE TRANS-URALS
}

\author{
Maria V. Orlova ${ }^{1,2^{*}}$, Anastasia A. Tomishina ${ }^{2,3}$ and Nikolay V. Anisimov ${ }^{2}$ \\ ${ }^{1}$ Tomsk State University, Tomsk, Russia \\ ${ }^{2}$ Institute of Environmental and Agricultural Biology (X-BIO), Tyumen State University, \\ Tyumen, Russia \\ ${ }^{3}$ State Nature Reserve "Malaya Sosva" named after V.V. Raevsky, Russia \\ "corresponding author; e-mail: masha_orlova@mail.ru
}

\begin{abstract}
We present the first record of Macronyssus heteromorphus Dusbábek et Radovsky, 1972 (Mesostigmata: Gamasina: Macronyssidae) in the Trans-Urals. Our record is located 1,500 km northwest from the nearest site of this species' previous record. The collected specimen (male) was found parasitizing a female of Myotis brandtii (Eversmann, 1845) (Chiroptera: Vespertilionidae). The records of both Macronyssus heteromorphus and its host species are the first ones in the Khanty-Mansi Autonomous Area. In this article, we present the measurements of this species for the first time, including the measurements that were omitted from the first description of this mite. Our finding also points to the existence of an area where Myotis brandtii and Myotis sibiricus Kastschenko, 1905 are sympatric.
\end{abstract}

KEY WORDS: Bats, gamasid mites, Macronyssus heteromorphus, Macronyssidae, Myotis brandtii.

DOI: 10.21684/0132-8077-2019-27-1-107-111

\section{INTRODUCTION}

The family Macronyssidae comprises obligatory and temporary parasites of mammals, birds and reptiles. The majority of this family's species are associated with bats (Chiroptera). Macronyssidae includes more than 30 genera that are known from the New and Old Worlds (Radovsky 2010).

The species belonging to the genus Macronyssus inhabit predominantly the Palearctic, where about 20 Macronyssus species have been recorded. Their hosts are usually bats of the family Vespertilionidae, most often of the genus Myotis (Orlova et al. 2017). With a rare exception, the species of the genus Macronyssus are either highly hostspecific (monoxenous) or they parasitize closely related bat species (oligoxenous).

The genus Myotis, after splitting off from a common ancestor in Southeast Asia approximately 25 million years ago, separated into two phylogeographic branches, which spread across the Palearctic in two opposite directions: Western Europe and the Far East. By now, these two branches have formed two independent faunal complexes in the boreal zone (Ruedi et al. 2013). The two groups have become isolated from each other due to physical landscape specifics of the western part of the West Siberian Plain. In particular, this area provided very few winter shelters for bats, which resulted in low densities of these animals.

The above factors resulted in the emergence of two independent faunal complexes of bat ectoparasites. Boreal Myotis-specific Macronyssus species usually have either a western Palearctic or an eastern Palearctic distribution. For example, $M$. diversipilis Vitzthum, 1920 falls into the former grouping, while the latter group is comprised of $M$. charusnurensis Dusbábek, 1962; M. hosonoi Uchikawa, 1979; M. sibiricus Orlova, Zhigalin, 2015; and, as it was considered previously, $M$. heteromorphus Dusbábek, Radovsky, 1972 (Orlova et al. 2017).

The possibility of Myotis species belonging to the eastern and western Palearctic faunal complexes being sympatric is strongly debated. Therefore, the study of ectoparasites in the KhantyMansi Autonomous Area (KMAA) is important because it may clear up the aforementioned issue. Here, we report the first record of the Macronyssus heteromorphus mite, collected from a non-specific host in the western part of KMAA. Our finding, which extends $M$. heteromorphus's geographic distribution, is unusual because this species is known to be ectoparasitic on eastern Palearctic bats. We discuss possible explanations of such an unusual finding.

\section{MATERIAL AND METHODS}

On July 15, 2018, we conducted a survey of birch hollows in the State Nature Reserve "Malaya Sosva", located in the Berezovskiy District, KMAA $\left(62^{\circ} 23^{\prime} \mathrm{N}, 64^{\circ} 04^{\prime} \mathrm{E}, 40 \mathrm{~m}\right.$ a.s.1., datum WGS84; coll. A.A. Tomishina) (Fig. 1). During our survey, the bats were captured using a but- 
terfly net. One specimen of M. heteromorphus (ð) parasitizing a presumably pregnant female of Brandt's bat Myotis brandtii (Eversmann, 1845) (Chiroptera: Vespertilionidae) was collected using a needle. The mite was mounted on permanent slides with Faure-Berlese's mounting medium (Whitaker 1988). Photographs were taken with a digital camera AxioCam ICc5 (Zeiss, Germany) via a compound microscope AxioImager A2 (Zeiss, Germany) with phase-contrast and DIC objectives. The specimen was deposited in the Entomological Collection of the Zoological Museum of Tyumen State University.

\section{RESULTS AND DISCUSSION}

We followed the original description of the species made by Dusbábek and Radovsky (1972). Males of $M$. heteromorphus can be easily distinguished from other Macronyssus spp. mainly by three pairs of long spine-like setae on posterior margin of the dorsal plate (Figs. 2). The measurements of the collected specimen are demonstrated in the table below.
M. heteromorphus was recorded before on the Kuril Islands on an atypical host - a gray rat Rattus norvegicus (Berkenhout, 1769). Previously, researchers thought that this mite was spread over the central and the eastern Palearctic regions. It was recorded in the Novosibirsk Region, the Altai Territory, the Republic of Khakassia, the Republic of Tuva, the Krasnoyarsk Territory, the Republic of Buryatia, the Russian Far East and Japan (Dusbábek and Radovsky 1972; Uchikawa 1979; Medvedev et al. 1991; Stanyukovich 1997; Orlova et al. 2015; Orlova et al. 2017a, b) (Fig. 1). Researchers have recorded $M$. heteromorphus on the following hosts: Siberian bat Myotis sibiricus Kastschenko, 1905; eastern water bat Myotis petax Hollister, 1912; David's bat Myotis davidii (Peters, 1869); Ikonnikov's bat Myotis ikonnikovi Ognev, 1912; northern bat Eptesicus nilssonii (Keyserling, Blasius, 1839); Siberian tube-nose bat Murina hilgendorfi Peters, 1880. Among the aforementioned hosts, the Siberian bat is associated with the most records. Apparently, small Myotis bats of the eastern Palearctic faunal complex are the main hosts of $M$.

Table 1

Comparison of body part measurements of males of Macronyssus heteromorphus from the Trans-Urals and Kunashir Island.

\begin{tabular}{|c|c|c|c|}
\hline Body part & Length, $\mu \mathrm{m}$ & Width, $\mu \mathrm{m}$ & References \\
\hline \multirow[t]{2}{*}{ Idiosoma } & 450.5 & 308.5 & Trans-Urals, this paper \\
\hline & 450,455 & - & Kunashir Island, Dusbábek Radovsky 1972 \\
\hline \multirow[t]{2}{*}{ Dorsal shield } & 405.8 & 275 & Trans-Urals, this paper \\
\hline & 388,392 & 231,243 & Kunashir Island, Dusbábek Radovsky 1972 \\
\hline \multirow[t]{2}{*}{ Longest caudal setae } & $66.7-73.5$ & - & Trans-Urals, this paper \\
\hline & 92 & - & Kunashir Island, Dusbábek Radovsky 1972 \\
\hline Holoventral shield* & 369.7 & 259 & Trans-Urals, this paper \\
\hline \multirow[t]{2}{*}{ Tarsus I } & 70 & - & Trans-Urals, this paper \\
\hline & 68,69 & - & Kunashir Island, Dusbábek Radovsky 1972 \\
\hline $\begin{array}{l}\text { Gnathosoma } \\
\text { (without palps) }^{*}\end{array}$ & 154.3 & 73.9 & \multirow[t]{5}{*}{ Trans-Urals, this paper } \\
\hline Palps* & 108.3 & - & \\
\hline $\begin{array}{l}\text { Chelicera (including } \\
\text { basal segment) }\end{array}$ & 110.8 & - & \\
\hline Fixed digit* & 15.4 & - & \\
\hline Movable digit ${ }^{*}$ & 33.5 & - & \\
\hline
\end{tabular}

*asterisk marks measurements lacking from the first description of M. heteromorphus. 
heteromorphus. However, these bats do not live in the "Malaya Sosva" Reserve. The closest locations, where eastern water bats were recorded, are the Korliki village (Orlova et al. 2013) and the Natural Reserve "Tigirekskiy" (Orlova et al. 2014) (both locations are along the $82^{\circ}$ longitude). Brandt's bat, which harbored the parasite specimen, belongs to the western Palearctic species complex and does not live east of the Trans-Urals (Skalon 1935; Raevskiy 1982; Bernikov and Starikov 2009; Starikov et al. 2009).

This study presents both the first record of $M$. heteromorphus in the Trans-Urals as well as the first record of this parasite species recovered from Brandt's bat. Our record is $1,500 \mathrm{~km}$ northwest from the previous nearest record (Fig. 1). Previously, this species was associated only with the eastern Palaearctic Myotis species complex. This finding alters our understanding of the spread of the eastern Palearctic species of bat ectoparasites.
Our discovery may also serve as a proof of the existence of an area where $M$. brandtii and $M$. sibiricus are sympatric. It is possible that this area is located along the part of the Ob River that flows between the cities of Nizhnevartovsk and KhantyMansiysk. In that area, the Ob River flows east to west, which allows bats to migrate in the sublatitudinal direction. This is due to the fact that welldrained river valleys, which are characterized by a reduced number of bogs, provide a sufficient number of shelters for bats (e.g., tree hollows, sand martin burrows and man-made structures).

Further research of bats and their ectoparasites on the territory of KMAA is necessary.

\section{ACKNOWLEDGMENTS}

We are very grateful to Oleg L. Orlov (Tyumen State University) and Sergey V. Kruskop (Zoological Museum of Lomonosov Moscow State University) for their helpful comments.

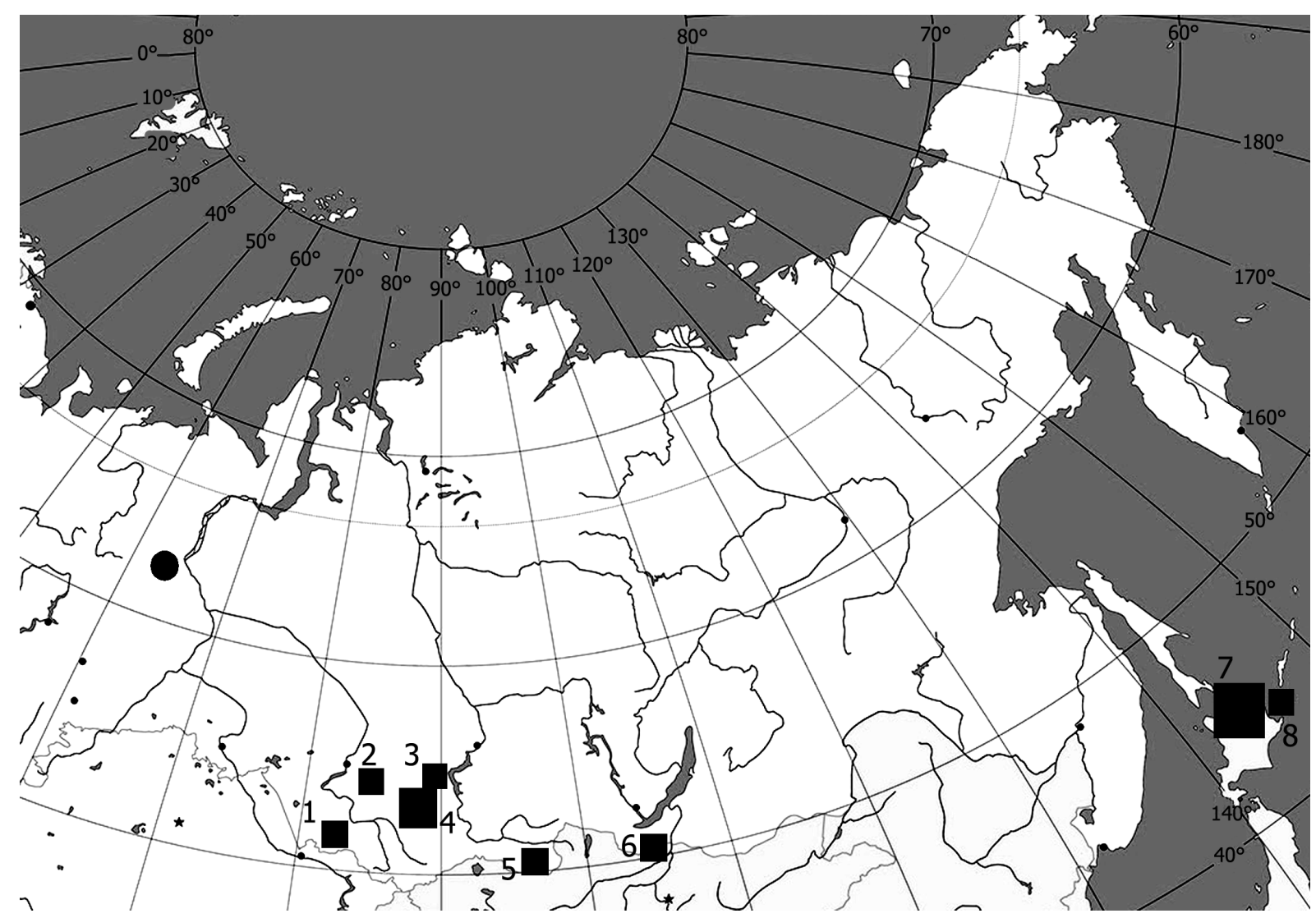

Fig. 1. Known (rectangles) and new (circle) record sites for the bat ectoparasitic mite Macronyssus heteromorphus Dusbábek et Radovsky, 1972 (Acari: Mesostigmata: Gamasina): 1. Natural Reserve "Tigirekskiy" (Altai Republic) (Orlova et al. 2017a); 2. Barsukovskaya cave (Novosibirsk Region) (Orlova et al. 2017a); 3. Arkheologicheskaya cave (Khakasia Republic) (Orlova et al. 2017a); 4. Ledyanaya, Zhenevskaya, Yashchik Pandory, Mayachnaya caves (Krasnoyarsk Region) (Stanyukovich 1997; Orlova et al. 2017a); 5. Uyuk River (Tuva Republic) (Orlova et al. 2015); 6. Dzhida River (Buryatia Republic) (new data); 7. Okedo, Memanbetsu, Sarobetsu, Tennin-kyo (Hokkaido, Japan) (Uchikawa 1979); 8. Kunashir Island (Sakhalin Region) (Dusbábek and Radovsky 1972). 


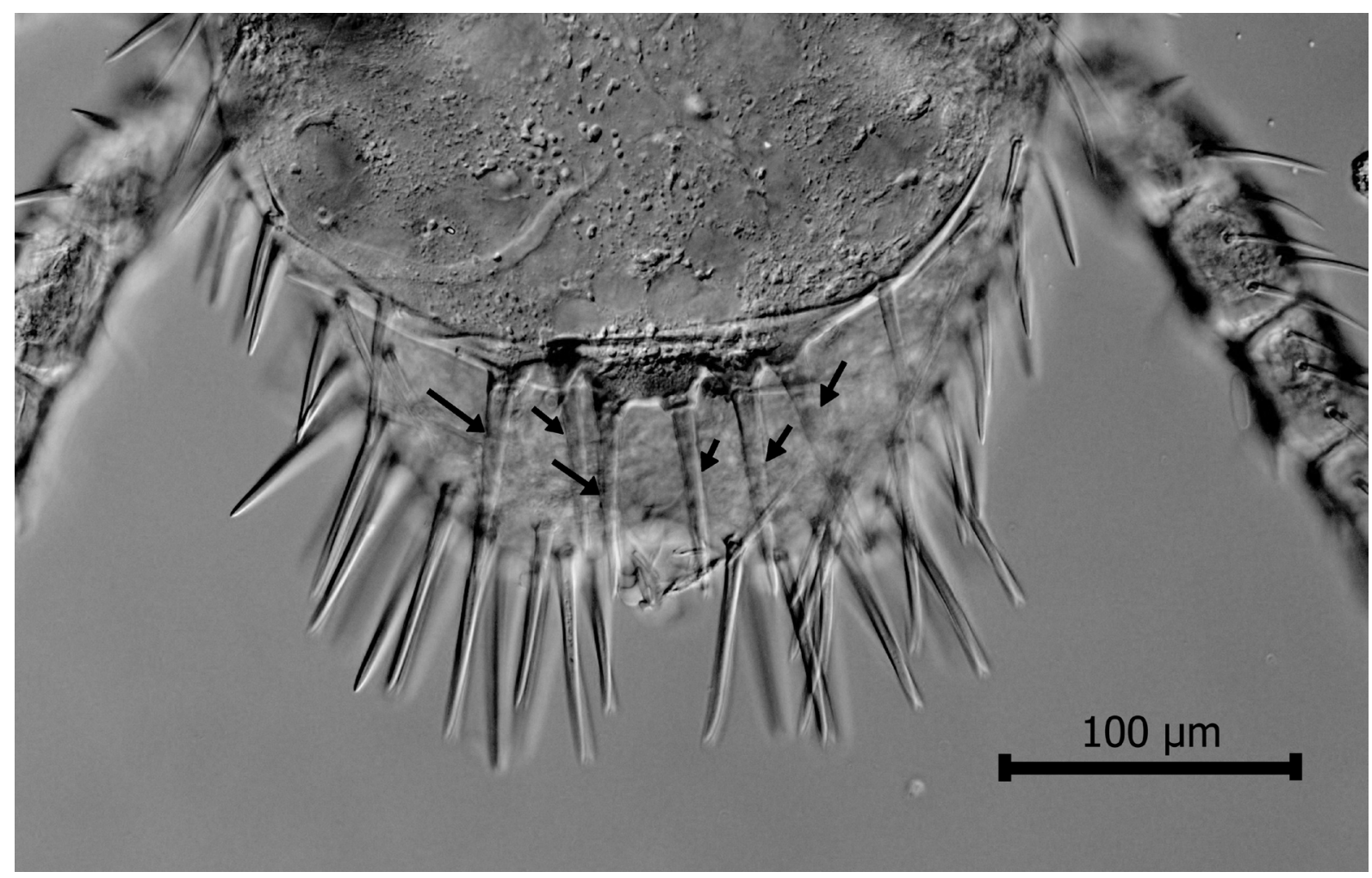

Fig. 2. Macronyssus heteromorphus, §̂, opisthosoma, arrows mark the long caudal setae.

The research was also supported by the Tomsk State University Competitiveness Improvement Program.

\section{REFERENCES}

Bernikov, K.A. and Starikov, V.P. 2009. [The fauna and ecological and biological features of bats (Chiroptera) of the Khanty-Mansiysk Autonomous Region]. Vestnik Orenburgskogo Gosudarstvennogo Universiteta, 2: 117-123. [In Russian]

Dusbäbek, F. and Radovsky, F.J. 1972. Macronyssus heteromorphus (Acarina: Macronyssidae) a new species from the Kuril Islands. Journal of Medical Entomology, 9 (6): 575-579.

Medvedev, S.G., Stanyukovich, M.K., Tiunov, M.P. and Farafonova, G.V. 1991. [Ectoparasites of bats from the Far East of USSR]. Parasitologia, 25, 1: 27-37. [In Russian]

Orlova, M.V., Kazakov, D.V., Kravchenko, L.B. and Zhigalin, A.V. 2017a. Ectoparasite fauna of the Siberian bat Myotis sibiricus (Chiroptera: Vespertilionidae) with a Revision of Previous Data on ectoparasites from Brandt bat Myotis brandtii s. 1. and the whiskered bat M. mystacinus s. 1. of the Eastern Palaearctic. Entomological Review, 97 (8): 1166-173.

Orlova, M.V., Orlov, O.L., Kazakov, D.V. and Zhigalin A.V. 2017b. Approaches to the identification of ectoparasite complexes of bats (Chiroptera: Ves- pertilionidae, Miniopteridae, Rhinolophidae, Molossidae) in the Palaearctic. Entomological Review, 97 (5): 684-701.

Orlova, M.V., Orlov, O.L., Kruskop, S.V. and Bernikov, K.A. 2013. Possibilities for identification of cryptic species of Chiroptera using host-specific ectoparasites. Biology Bulletin, 40 (1): 111-113.

Orlova, M.V., Orlov, O.L. and Zhigalin, A.V. 2014. New records of ectoparasites of the eastern water bat Myotis petax Hollister, 1912 (Vespertilionidae, Chiroptera) and the revision of the material previously collected from Myotis daubentonii s. lato in the Eastern Palaearctic. Entomological Review, 94 (9): 1306-1312.

Orlova, M.V. and Zhigalin, A.V. 2015. Three new bat ectoparasite species of the genus Macronyssus from Western Siberia (with an identification key for females of the genus Macronyssus from the Palearctic boreal zone). Journal of Parasitology, 101 (3): 314-319.

Orlova, M.V., Zhigalin, A.V. and Khritankov, A.M. 2015. New findings of bat (Chiroptera: Vespertilionidae) ectoparasites in Southern Siberia. Entomological Review, 95, 5: 681-686.

Radovsky, F. 2010. Revision of genera of the parasitic mite family Macronyssidae (Mesostigmata: Dermanyssoidea) of the World. Indira Publishing House, West Bloomfield, Michigan, p. 170. 
Rayevskiy, V.V. 1982. Pozvonochnye zhivotnye Severnogo Zauralia [Vertebrates of the Northern TransUrals]. Nauka, Moscow, 148 pp. [In Russian]

Ruedi, M., Stadelmann, B., Gager, Y., Douzery, E.J.P., Francis, C.M., Lin, L.-K., Guillen-Servent, A. and Cibois, A. 2013. Molecular phylogenetic reconstructions identify East Asia as the cradle for the evolution of the cosmopolitan genus Myotis (Mammalia, Chiroptera). Molecular Phylogenetics and Evolution, 69: 437-449.

Skalon, V.N. 1935. [New data on the fauna of mammals and birds of Siberia and the Far Eastern region]. Izvestiya Protivochumnogo Instituta Sibiri i Dalnevostochnogo Kraya, 2: 42-64. [In Russian]

Stanyukovich M.K. 1997. Keys to the gamasid mites (Acari, Parasitiformes, Mesostigmata, Macronyssoidea et Laelaptoidea) parasiting bats (Mamma- lia, Chiroptera) from Russia and adjacent countries. Rudolstädter Naturhistorische Schriften, 7: 13-46.

Starikov, V.P., Bernikov, K.A. and Nakonechnyi, N.V. 2009. [Population of small mammals in the Verkhne-Kondinsky reservation]. In: O.E. Philatova et al. (Eds.). Ecologia i prirodopol'zovanie v Yugre. Materialy nauchno-prakticheskoi konferentsii, posvyaschennoi 10-letiy kafedry ekologii SurGU (16-17 October 2009, Surgut, Russia). Abstracts. Surgut State University, Surgut, p. 142-143. [In Russian]

Uchikawa, K. 1979. Bat mites of the genus Macronyssus Kolenati (Acari, Macronyssidae). Annotationes zoologicae japonenses, 52 (4): 246-256.

Whitaker J. O. Jr. 1988. Collecting and preserving ectoparasites for ecological study. Ecological and Behavioral Methods for the Study of Bats. In: T.H. Kunz (Ed.). Smithsonian Institution Press, Washington, pp. 459-474. 